\title{
THE UTILIZATION OF GRASSES, LEGUMES, AND OTHER FORAGE CROPS FOR CATTLE FEEDING IN PUERTO RICO

\author{
III. COMPARISON OF FERTILIZED GUINEA GRASS, PARA GRASS, \\ TROPICAL KUDZU AND GUINEA GRASS, AND \\ TROPICAL KUDZU
}

L. Rivera Brenes, F. J. Marchán, and J. I. Cabrera ${ }^{1}$

\section{INTRODUCTION}

This paper reports the third of a series of grazing trials started in 1945 for the evaluation of the most important pasture crops found in the Island and of those introduced.

As recommended by the Joint Pasture Research Committee (1) ${ }^{2}$ a duration for pasture experiments of 6 to 10 years is preferable, but we think that under our conditions, where we have some 365 grazing days annually, such a long time is not needed to get reliable results. The only large climatic variation in the Island is in rainfall. There is a 2- or 3-month dry period during the year, especially in the southern part of the Island. The northern part of the Island has been fortunate in this respect for the past 3 years.

The results of these grazing trials have been reported individually in order to have the information available to the farmers as soon as possible. After the end of the fourth trial, finished in 1950, all the data will be compiled in one final report.

\section{Literature Review}

In the first grazing trial (2) the carrying capacity of the Para grasstropical kudzu mixture was 1 head and in the second trial (3) it was also nearly 1 head per acre. Unfertilized Guinea grass had a carrying capacity of 0.5 in the first trial and for the second trial; when fertilized, its carrying capacity was increased to 1.12 heads per acre.

In these two trials it was also found that fertilization increases the protein content as well as the total tonnage. Planting a legume in association with the grass not only increases both the yield and the protein content of the grass, but also renders both far more uniform.

\section{Procedure}

The procedure followed was the same as that for the first trial (2). The grasses compared were mixtures of Para grass-kudzu, Guinea grass-kudzu,

${ }^{1}$ Acting Head, Animal Husbandry Department, Assistant Chemist, and Assistant Animal Husbandman, respectively, Agricultural Experiment Station, University of Puerto Rico, Río Piedras, P. R.

${ }^{2}$ Numerals in parentheses refer to Literature Cited, p. 113-14. 
and Guinea grass alone. This time Guinea grass was fertilized with 100 pounds of ammonium nitrate per acre at the beginning of the trial and a second application of 200 pounds of ammonium sulfate per acre 3 months later. To save time in the establishment of the Guinea grass-kudzu mixture, the Guinea grass was planted in the old kudzu stand. The land was not plowed, to avoid killing the already established kudzu, but was furrowed with a small plow at the proper distance. Pieces of roots were used and in 7 months an excellent Guinea grass-kudzu mixture was obtained.

The heifers used were Holstein-Native, Brown-Swiss-Native crosses, and pure-bred Holsteins. They were distributed among the grasses to avoid breed differences. The trial lasted 221 days, and was divided into three periods, according to the number of animals grazing each grass at one time. During the first and third periods there were 2 heifers per acre-plot of grass and during the second period 2 heifers in each acre-plot of Para grass-kudzu and Guinea grass-kudzu and one in each acre of Guinea grass alone. When calculating gain in weight and differences in gain in weight, periods 1 and 3 were combined and analyzed separately from period 2 . Total digestible nutrients and carrying capacity were calculated for the trial as a whole, using the coefficients of digestibility recommended by the Pasture Research Committee (1) instead of 72 percent of the dry matter as in previous trials.

\section{Results and Discussion}

As in previous reports weight gains and differences are presented in table 1 to show the probable differences in nutritive value between the grasses and legume-grass mixtures.

There was no significant difference between the average gain in weight of the animals that grazed on Para grass-kudzu and on Guinea grass-kudzu mixture for the first and third periods together. The differences between the mean gain in weight in the legume-grass mixtures and Guinea grass alone were significant at the 5 -percent level. No significant difference was found between the mean gains in weight during the second period. The most probable explanation of the results obtained in the second period is the following: The Guinea grass plots were fertilized with ammonium sulfate the same day (8-4-48) this second period started. The addition of nitrogen to the soil improved the nutritive value of the grass considerably. This assumption is sustained by the average daily gain in weight per animal. During the first and third periods together the average daily gain on Guinea grass was 0.30 pounds, and for the second period 1.19 pounds; of course, we must consider that the lengths of the periods 158 and 63 days, respectively, might have affected the averages. In general, the daily gain in weight per animal for the first and third periods together for all the roughages in the trial was lower than in the second period, for Para grass-kudzu, 0.68 
pounds and 1.09 pounds per animal, and for Guinea grass-kudzu 0.62 pounds and 1.17 pounds, respectively.

The average chemical analyses for the grass samples taken during the grazing trial are presented in table 2 .

TABLE 1.-Gain in pounds per group, mean gain per animal, and least significant difference

\begin{tabular}{|c|c|c|c|c|c|c|}
\hline Grasses & Heifers & $\begin{array}{c}\text { Initial } \\
\text { weight } \\
\text { of groups }\end{array}$ & $\begin{array}{l}\text { Weight } \\
\text { of groups } \\
\text { at end of } \\
\text { period }\end{array}$ & $\begin{array}{c}\text { Gain of } \\
\text { groups }\end{array}$ & $\begin{array}{l}\text { Mean } \\
\text { weight } \\
\text { per } \\
\text { animal }\end{array}$ & $\begin{array}{l}\text { Least significant } \\
\text { differences }\end{array}$ \\
\hline
\end{tabular}

First and third periods together 5-12-48 to 8-3-48 and 10-6-48 to 12-18-48

\begin{tabular}{|c|c|c|c|c|c|c|}
\hline & Number & Pounds。 & Pounds & Pounds & Pounds & \\
\hline PK.... & 3 & 862 & 1,097 & 235 & 78.33 & \\
\hline PK......... & 3 & 1,270 & 1,677 & 407 & 135.67 & \\
\hline GK... & 3 & 761 & 1,008 & 247 & 82.33 & $\begin{array}{c}69.12 \text { at } 5 \text {-percent } \\
\text { level }\end{array}$ \\
\hline GK........ & 3 & 1,103 & 1,444 & 341 & 113.67 & $\begin{array}{c}159.60 \text { at } 1 \text {-percent } \\
\text { level }\end{array}$ \\
\hline$G \ldots \ldots \ldots$ & 3 & 932 & 1,052 & 120 & 40.00 & \\
\hline G.......... & 3 & 832 & 1,004 & 172 & 57.33 & \\
\hline
\end{tabular}

Second period 8-4-48 to $10-5-48$

\begin{tabular}{l|l|l|l|l|l|l}
\hline PK......... & 3 & 1,279 & 1,451 & 172 & 57.33 & \\
PK......... & 3 & 1,229 & 1,469 & 240 & 80.00 & \\
GK........ & 3 & 1,059 & 1,278 & 219 & 73.00 & 45.75 at 5-percent \\
level \\
GK......... & 3 & 1,273 & 1,499 & 226 & 75.33 & \\
G........... & 3 & 1,004 & 1,228 & 224 & 74.66 & \\
\hline
\end{tabular}

${ }_{1}$ The final weights for these animals were taken as the initial weight plus the gain in weight during the first and third periods because the second period was analyzed separately.

TABLE 2.-Average analysis of the three forage crops during the whole trial on a dry basis

\begin{tabular}{|c|c|c|c|c|c|c|c|}
\hline Grasses & Samples & Moisture & Ash & $\begin{array}{l}\text { Crude } \\
\text { protein }\end{array}$ & Fat & Fiber & $\begin{array}{l}\text { Nitrogen- } \\
\text { free extract }\end{array}$ \\
\hline & Number & Percent & Percent & Percent & Percent & Percent & Percent \\
\hline PK. & 33 & 75.86 & 8.58 & 9.83 & 1.34 & 32.10 & 48.25 \\
\hline GK. & 33 & 76.6 & 9.52 & 8.34 & 1.19 & 35.85 & 45.12 \\
\hline G........ & 33 & 70.24 & 9.43 & 5.21 & 1.07 & 36.11 & 48.12 \\
\hline
\end{tabular}

The crude-protein content of the legume-grass mixtures is higher than that of the grass alone. This is to be expected, and was true in this and the previous trials (1-3). Guinea grass received only two fertilizations insteap of three, as was the case in the second experiment. The reason for this was 
that fertilizer was applied according to the condition of the grass that is, its color and growth. In trial No. 2 (3) the average protein in the Guinea grass was 8.56 per cent and in this trial only 5.21 percent, dry basis. This might be attributed to the fertilizer received during the experimental periods, and also to the difference in quality of the samples taken from the clippings. The grass received only two applications of nitrogen because, as pointed out above, observations indicated that it was green and having good growth.

The crude protein of the mixture of Guinea grass and kudzu compares very well with the over-all content for fertilized Guinea grass in trial No. 2 (2), 3.34 and 8.56 per cent, respectively. The results obtained emphasize the importance of the legumes in grass mixtures.

Nothing was clipped from the Para grass-kudzu plots during the entire experimental period. Table 3 presents the data for clippings from the other two roughages and their dry-matter content. No residue was clipped during the third period in any of the roughages.

TABLE 3.-Clippings and dry-matter content of the grasses in pounds, by periods ${ }^{1}$

\begin{tabular}{|c|c|c|c|c|}
\hline \multirow{2}{*}{ Grasses } & \multicolumn{2}{|c|}{ First period } & \multicolumn{2}{|c|}{ Second period } \\
\hline & Clippings & Dry matter & Clippings & Dry matter \\
\hline & Pounds & Pounds & Pounds & Pounds \\
\hline PK. & - & - & - & - \\
\hline GK. . & 20,303 & $4,742.78$ & 750 & 175.20 \\
\hline G...... & 3,908 & $1,663.02$ & 5,929 & $1,764.47$ \\
\hline
\end{tabular}

${ }_{1}$ No clippings in the third period.

As pointed out in the procedure, the Guinea grass was planted in the old kudzu stand, hence was favored by a large accumulation of nitrogen in the soil. The growth obtained during the pre-experimental period was exuberant. Of the 20,303 pounds of clippings from the Guinea grass-kudzu mixture during the first period, 18,810 pounds were obtained after the first rotation in the 3 acres. From then on the heifers ate nearly all the roughage produced. This is demonstrated by the small quantity obtained in the second period, and none in the third.

The effect of the fertilization of the Guinea grass is shown by the increase in the quantity of clippings in the second period as compared with the first. An application of ammonium sulfate was made just at the start of the second period.

The calculated carrying capacity is presented in table 4 .

Although the Guinea grass plots looked in good condition with only two applications of nitrogen, the carrying capacity was lower than in trial No. 2 (3). Apparently two applications of nitrogen were not enough to maintain the grass as in the previous trial. It is the opinion of the investigator that 
these variations can be expected because of the different animal and climatic factors affecting the results. Analyzing periods Nos. 1 and 3 (158 days) separately from period No. 2, (63 days) the carrying capacity was 0.58 and 0.92 , respectively. The results in the second trial demonstrate the favorable effects of nitrogen fertilization. The same thing had been happening with the Para grass-kudzu mixture, although the variation was not great. The results obtained with the mixture of Guinea grass-kudzu are encouraging; kudzu mixes very well with the grass and there was no sign of incompatibility, but further trials are need to determine this.

TABLE 4.-Approximate carrying capacity for the grasses on trial

\begin{tabular}{|c|c|c|c|}
\hline Grass & Cow-days & Days on trial & Carrying capacity \\
\hline & & Days & Head \\
\hline PK. . & 169.73 & 221 & 0.77 \\
\hline GK... & 241.61 & 221 & 1.09 \\
\hline $\mathrm{G} \ldots \ldots \ldots \ldots \ldots$ & 149.70 & 221 & .68 \\
\hline
\end{tabular}

The statistical analysis of the calculated total-digestible-nutrient yields is given below for the entire experimental period:

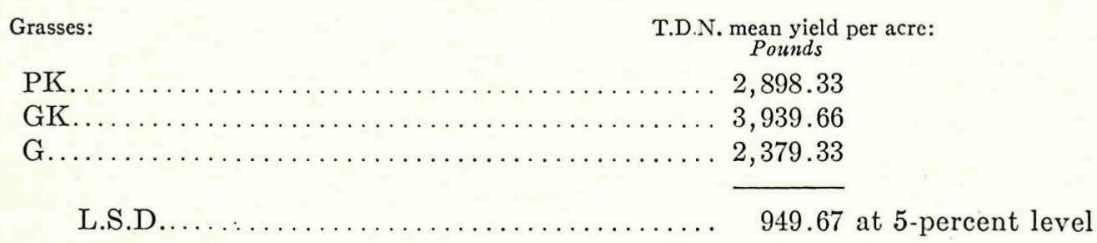

There was no significant difference at the 1-percent level.

The mixture of Guinea grass-kudzu was superior in T.D.N. yield to the other forages tested. This resulted, of course, from the larger quantity of clippings during the first period. As explained before, the Guinea grass in the mixture had the benefit of the accumulation of nitrogen in the soil which produced an exuberant growth before the experiment started. When the heifers were put to graze on it they were not able to eat all the roughage at the time the other grass subplots were due for rotation. There was no significant difference between Guinea grass alone and Para grass and kudzu.

The rainfall figures for the 8 months of the trial are shown in the following tabulation from records kept by the Experiment Station farm:

\begin{tabular}{|c|c|}
\hline Month & $\begin{array}{l}\text { Rainfall } \\
\text { (Inches) }\end{array}$ \\
\hline May. & 10.91 \\
\hline June. & . 8.01 \\
\hline July. . & . 8.79 \\
\hline Augus & $\therefore 7.33$ \\
\hline
\end{tabular}

\begin{tabular}{|c|c|}
\hline Month & $\begin{array}{l}\text { Rainfall } \\
\text { (Inches) }\end{array}$ \\
\hline September.............. & 10.07 \\
\hline October................. & 4.14 \\
\hline November................ & 9.69 \\
\hline December................ & 9.85 \\
\hline
\end{tabular}


The water supply was more or less the same as for the previous trial. The monthly average was 7.35 inches of rainfall, which eliminates this as a factor affecting growth.

Everything tends to indicate that the mixture of Guinea grass and kudzu is a good combination for pasture. They mix well and apparently there is no incompatability, but because Guinea grass is better adapted to dry areas, it needs further investigation in other places around the Island.

The results obtained for Para grass-kudzu vary somewhat from those obtained before (1-3). As this is something to be expected, and the difference is not great, it is the opinion of this investigator that this roughage has been performing uniformly throughout.

There is no doubt as to the benefits of nitrogen fertilization of grasses; this has been demonstrated in two consecutive trials with Guinea grass. But in the long run, the use of a legume will be more economical from all points of view.

\section{Summary and Conclusions}

A third grazing trial of 221 days was conducted under the same procedure as in trial No. 1 (2). A modification was introduced in that the calculation of T.D.N. was made using the chemical analysis of the roughages, and the digestion coefficients given by the Pasture Research Committee (1).

The grasses under trial were, Para grass-kudzu, in its third year, Guinea grass-kudzu, in its first year, and fertilized Guinea grass, and its second year. In this experiment Guinea grass received only two applications of nitrogen instead of three as in trial No. 2. According to our observations this was because the grass was growing well and had a nice green color. Nitrogen was applied when the leaves began turning yellowish.

Para grass-kudzu was uniform in performance, the carrying capacity being 1 head in the first trial, 1 head in the second, and 0.77 head for this trial. The carrying capacity of the mixture of Guinea grass and kudzu was 1.09 , but since this grass was planted in the old kudzu stand, it received the benefits of the nitrogen accumulation in the soil producing an exuberant growth at the beginning of the trial. As a result, larger quantities of residue were clipped after rotations affecting the carrying capacity favorably. Although the results are encouraging, further investigations are needed to to make definite recommendations.

Guinea grass alone had a carrying capacity of 0.68 head. It was lower than in the previous trial. The difference can be attributed to the difference in nitrogen supplied, as nitrogen increases the quantity of roughage produced and its nutritive value.

\section{Literature Cited}

1. Preliminary Report on Pasture Investigations Technics, Joint Committee of the American Society of Agronomy, American Dairy Science Association, and American Society of Animal Production, Jour. Dairy Sci. 26 353-369, 1943. 
2. Rivera-Brenes, L., The utilization of grasses, legumes, and other forage crops for cattle feeding in Puerto Rico: I, Comparison of Para grass, Para grasskudzu and Guinea grass as pasture crops, Jour. of Agr., Univ. P. R. 31 (2) 1947. Rico 31(2) 1947.

3. Rivera-Brenes, L., Marchán, F. J., and Cabrera, J. I., The utilization of grasses, legumes, and other forage crops for eattle feeding in Puerto Rico: II. Comparison of Para grass-kudzu, kudzu alone and fertilized Guinea grass as pasture crops, Jour. of Agr., Univ. P. R., 33(3) 1949. 